\title{
POTRET NILAI KESUFIAN DALAM KEHIDUPAN BERMASYARAKAT
}

\author{
Danial Hilmi \\ Fakultas Humbud UIN Maliki Malang, J1. Gajayana No.50 Malang \\ Email: danialhilmi@gmail.com
}

\begin{abstract}
The value of Sufism has appeared since the time of Prophet Muhammad SAW, so it is not difficult to trace when the seeds of Sufism began to emerge. In fact, the adherents of Sufism are regarded as the ancient society that is antipathy to the modernization and staying away from the life of the world. In fact, this assumption is wrong and far from the values of the truth of Sufism, because the actual teachings of Sufism in the community is to contribute the development of the society into a better society.
\end{abstract}

Keywords: Value if Sufism, Life, Society

\begin{abstract}
Abstraksi
Nilai-nilai sufisme telah ada sejak masa Nabi Muhammad SAW, oleh karena itu tidak begitu sulit untuk mendapatkan informasi tentang jejak kemunculannya. Berdasarkan asumsi masyarakat, para penganut sufisme dianggap sebagai masyarakat kuno yang antipati terhadap modernisasi dan menjauhi kehidupan duniawi. Sebenarnya, asumsi tersebut adalah salah dan jauh dari nilai-nilai kebenaran sufisme, karena pada dasarnya pengajaran kesufian dalam masyarakat bertujuan memberikan kontribusi terhadap perkembangan masyarakat yang lebih baik.
\end{abstract}

Kata kunci : Nilai kesufian, kehidupan masyarakat.

\section{Pendahuluan}

Dalam kehidupan bermasyarakat, tidak bisa dilepaskan dengan etika dan norma yang selalu menghiasi setiap langkah manusia sebagai makhluk sosial. Manusia sepanjang perjalanan sejarah memerankan sosok yang haus akan pengetahuan, sebagaimana dalam pencarian Tuhan sebagai Dzat yang menciptakan dan membimbing manusia menjadi ciptaan yang tidak ternilai.

Dengan didorong oleh keingintahuan kepada Tuhannya, sehingga manusia selalu mencari kemanakah arah hidup ini, dan apa yang harus dilakukan untuk dapat mendekatkan diri dengan Tuhannya. Dunia pencarian Tuhan menawarkan intuitif yang sering dicari manusia yang berada dalam keputusan rasionalitas dan intelektual. Pada saat rasionalitas tidak dapat menemukan jawaban, pada saat itu pula manusia 
merasakan gersang dan berupaya menggerakkan intuisinya sebagai alternatif dalam menemukan jawaban.

Tasawuf mempunyai warna tersendiri dengan kondisi pelaku dan waktu yang melingkupinya. Memang terkadang sulit merasionalkan tasawuf dengan rasionalitas. Karena sebagian diantaranya adalah pengetahuan yang tidak dapat dibuktikan oleh pengetahuan rasionalitas yang begitu deskriptif dan definitif. Ia adalah pengetahuan subjektif yang masing-masing orang berbeda persepsi, satu titik yang bertolak belakang dengan objektifitas yang jadi ukuran utama kebenaran dalam rasio. Apapun definisinya tidak akan pernah bisa mengungkapkan hal yang sebenarnya. Layaknya definisi mawar tidak akan pernah bisa merasakan keindahan mawar itu sendiri. Jadi wajar jika dalam perjalanannya ia tetap menjadi ulasan sepanjang waktu, perdebatan para pakar, menghasilkan banyak sarjana, bukan saja dalam dunia Islam tapi juga dalam dunia orientalisme.

Pengalaman ghaib didapat melalui suluk, maka seorang pengembara harus mencapai puncak ma'rifat Allah yang mana merupakan tujuan akhir dan sekaligus merupakan tingkat kebahagiaan paripurna yang mungkin dicapai manusia di dunia ini (Siregar, 2000:40)

Bagaimanapun model tasawufnya secara umum semua penganutnya yakin bahwa apa yang dilakukan adalah memang dituntutkan oleh Rasulullan. Dalam tulisan ini akan dibahas bagaimana perkembangan tasawuf sehingga memiliki semangat dan gairah yang tinggi dalam upaya mempertahankan kedaulatan bangsa dan ikut andil dalam kehidupan modernitas tanpa ketinggalan dengan segala pernakpernik kehidupan dunia.

\section{Potret Perkembangan Ajaran Tasawuf}

Masuknya Agama Islam ke Indonesia membawa sebuah pemikiran bahwa tersebarnya Islam bukan karena misi tertentu juga bukan karena sebuah penjajahan yang membawa kepada kesengsaraan, tetapi Agama Islam membawa kedamaian dan keselamatan bagi penganutnya serta orang-orang di sekelilingnya. Jika merunut pada berbagai negara tentunya memiliki motif yang berbeda dengan negara Indonesia, kalau di negara Eropa sistem penyebarannya melalui ekspansi dan dakwah, di 
beberapa negara Asia dilakukan dakwah secara terang-terangan, sementara di Indonesia tidak tampak melainkan melalui jalur perdagangan.

Penyebaran Agama Islam di Indonesia pada umumnya berawal dari para saudagar yang melakukan kegiatan perniagaan serta membawa pesan dakwah Islam. Hubungan dagang memang sudah terjalin antara India dan Cina, sehingga bermula dari para saudagar dari Gujarat yang telah mendapatkan Islam melalui jalur Laut Merah dan Selat Malaka, sehingga dengan cara melakukan transaksi jual beli yang pada saat itu pulalah diselipkan ajaran agama Islam yang membawa rahmat bagi seluruh alam.

Pernah ada ahli sejarah Islam yang mengatakan bahwa pada periode pemerintahan Yazid bin Mua'wiyah didapati sekelompok keluarga Arab di Pesisir barat pulau Sumatera. Namun pada kisaran abad ke-3 dan ke-4 Hijriyah di zaman keemasan Daulah Bani Abbasiyah di Baghdad terdapat banyak kalangan pelajar dan pengembara yang tinggal disana.

Setelah Indonesia jatuh ke tangan Belanda, mereka menetapkan secara langsung bahwa Islam masuk ke Indonesia pada abad ke-13 M, karena waktu itu berdiri kerajaan Islam di Samudera Pasai. Hal ini bisa dimaklumi karena sudah menjadi kebiasaan bahwa memulai sejarah itu diawali dengan berdirinya suatu kerajaan. Sementara pada abad ke-14 dan ke-15 juga berdiri Kerajaan Malaka di Semenanjung Tanah Melayu, demikian juga Kerajaan Islam di Maluku dan Ternate.

Dengan didorong rasa dengki yang sangat dalam diantara kerajaan Kristen dan pasca runtuhnya Kerajaan Islam di Andalusia, maka bangsa Portugis menyerang Malaka sehingga dikuasai. Sementara di akhir abad ini datanglah pasukan Belanda yang memasuki wilayah Banten di bagian Barat Pulau Jawa. Dengan demikian mereka secara bertubi-tubi dengan berbagai cara baik melalui kekerasan maupun tipuan menyerang sekaligus memanfaatkan penyebaran Kristen dan hasil alam yang melimpah.

Dengan mengerahkan segala daya dan upaya serta tipu muslihat, maka para penjajah yang membawa misi menyebarkan agama Kristen berusaha menghapus pengaruh Islam yang menjadi latar belakang kekuatan bangsa Indonesia dengan berbagai senjata dan strategi untuk mengikis habis kekuatan Islam. Selama 350 tahun 
usaha pemusnahan tidak kunjung membawa hasil karena atas lindungan Allah, maka cahaya Islam tidak bisa dikikis dari bumi Indonesia.

Masuknya Portugis ke Indonesia membawa kesegaran datangnya penjajah lain seperti Belanda, Perancis, Inggris, dan Spanyol ke wilayah Indonesia dan sekitarnya karena wilayah ini mulai berkembang ajaran Islam yang semakin kuat. Selama 4 abad penduduk Indonesia berjuang mempertahankan ajaran Islam agar tidak lekang oleh waktu dan ditaklukan seiring datangnya penjajah ke negeri ini.

Mereka datang ke negeri ini bermaksud mengambil dengan paksa agar berkuasa dan mendudukinya, mulai menguasai kekuasaan sampai kekayaan alam yang subur untuk dapat hidup bertahan dan berkuasa di Indonesia, tetapi mereka tidak sanggup mengambil satu hal, yaitu Iman dan kepercayaan masyarakat terhadap agama Islam.

Pasca jatuhnya perang global antara Islam dengan kaum Nasrani di Barat yang dinamakan Perang Salib, kerajaan Islam yang berada di kekuasaan Bani Abbasiyah yang berpusat di Baghdad runtuh dan dikuasai pasukan Mongol dan Tartar, pada saat itu kaum muslimin juga merasakan pengalaman pahit dimana kekuasaan di Spanyol juga direbut, sehingga cahaya Islam nyaris lenyap di hampir seluruh Dunia Islam. Demikian juga yang dialami oleh masyarakat Islam di Indonesia yang mengalami hal yang sama yaitu penjajahan yang bertubi-tubi oleh negara-negara barat yang secara sporadis menghantam negeri ini.

Masyarakat Indonesia kala itu benar-benar mendapatkan ujian yang hebat, sementara negeri ini jauh dari pusat peradaban dan kegiatan Islam di Dunia Islam, padahal dunia Islam sebagai pusat juga jatuh ke tangan negeri non muslim, sehingga masyarakat Indonesia mengalami kejumudan berpikir untuk mendapatkan petunjuk dari pusat dunia Islam. Pada saat itu, banyak masyarakat kita membawa ajaran tasawuf yang lebih menekankan pada ajaran pasrah atas apa yang telah dianugerahkan Allah pada mereka. Hal ini tentunya menghambat perjuangan masyarakat yang ingin segera bebas dari belenggu penjajahan, sementara negaranegara penjajah akan terus memborbardir sebelum keyakinan masyarakat hilang dari hati mereka.

Semakin gencarnya agresi yang disarangkan pada rakyat Indonesia, membuat masyarakat tidak tinggal diam sehingga terjadilah pemberontakan untuk mengusir 
penjajah dari tanah air ini. Mulai dari Pangeran Diponegoro di wilayah Jawa sampai Tuanku Imam Bonjol di Sumatera Barat yang berlatar belakang penganut Tarekat dalam tasawuf ikut berpartisipasi mempertahankan kemerdekaan Indonesia dari cengkeraman kaum agresor.

Begitu totalnya perjuangan rakyat Indonesia, seiring jumlah musuh yang lebih banyak dan dilengkapi senjata yang lebih lengkap maka segala perlawanan yang dilakukan seakan sirna dan mudah dipatahkan karena senjata yang dipergunakan juga sederhana, sehingga begitu banyak rakyat yang mati baik di medan pertempuran maupun mati di tempat pengasingan seperti yang dialami oleh Sultan Hasanuddin dan pahlawan yang lainnya.

Kematian demi kematian yang terus melanda bumi Indonesia tidak mematahkan semangat rakyat untuk terus berjuang dan mempertahankan kemerdekaan Indonesia dari para penjajah. Mereka rela mati sampai titik darah penghabisan dengan iming-iming hidup mulia atau mati syahid, sehingga slogan ini begitu melekat pada rakyat demi terwujudnya martabat bangsa Indonesia.

Pada saat itu juga berangkatlah beberapa putra Indonesia ke Makkah al Mukarramah untuk menunaikan ibadah haji serta menimba ilmu agama Islam disana. Diantara mereka terdapat Syaikh Nawawi Banten, Syaikh Ahmad Khatib al Minangkabawi dan lain sebagainya. Mereka mempelajari berbagai bidang ilmu agama Islam seperti Tafsir, Hadits, Fiqh, Ushul Fiqh dan lain-lain. Sebagian diantara mereka pulang ke tanah air tetapi tidak membawa konsep baru untuk pembaruan, karena Makkah saat itu dinaungi suasana taqlid kepada Ulama-ulama terdahulu. Guru-guru mereka mengajarkan bahwa pintu ijtihad tertutup untuk selama-lamanya, sebab permasalahan zaman ulama terdahulu tidak meninggalkan perkara baru yang perlu diperbincangkan. Namun sebagian mereka tidak mau pulang ke tanah air karena tidak tahan melihat penjajahan yang menimpa negerinya sehingga memilih menetap di Makkah sampai wafat di sana.

Ajaran Islam yang dipelajari membawa pengaruh terhadap kehidupan masyarakat, hal ini tampak dalam sikap pantang menyerah membela negara yang merupakan bagian dari Iman. Ajaran tasawuf di Indonesia memiliki motif yang berbeda dan terbilang sebagiannya bernuansa ala Indonesia. Seperti halnya ajaran Sunan Kalijogo yang mengakomodasi budaya Jawa dalam berdakwah. 
Dunia sufi tidak asing di segala penjuru dunia, mereka dapat hidup berdampingan sesuai dengan karakteristik mereka dengan tetap menjaga keutuhan muqarabah mereka kepada Sang Khalik. Dalam banyak realita menunjukkan bahwa para kaum sufilah yang mengantarkan perjuangan kemerdekaan dan mempertahankan kedaulatan suatu negara.

Penganut sufi merupakan kalangan elit yang sering memimpin berbagai gerakan pembaharuan dan melakukan perlawanan terhadap penindasan dan hegemoni penjajah. Mereka banyak terlibat dalam gerakan politik sebagaimana pada kebangkitan Maroko dan Aljazair dalam melawan Perancis, serta pembangunan kembali masyarakat dan pemerintahan Islam di Libya yang sebagian dilakukan oleh penganut tarekat Sanusi.

Seorang penganut tarekat Qadiriyah Syaikh Utsman di Nigeria memimpin jihad melawan para penguasa Habe yang tidak berhasil memerintah berdasarkan syari'at Islam serta memberlakukan pembebanan pajak yang manipulatif, melakukan kejahatan korupsi, menindas rakyat dan tidak berhasil menjaga martabat Islam pada masyarakat. Lebih dari itu, kaum penganut tarekat Naqsabandiyah dan Syah Waliyullah menentang kekuasaan kolonial Inggris di India sehingga tidak ada celah bagi penjajah untuk leluasa melakukan serangkaian agresi di negara mereka.

Contoh di atas hanyalah sebagian dari banyak reaksi yang ditunjukkan mereka, penentangan pada usaha kolonial dalam penjungkiran pemerintahan Islam serta mereka memiliki tekad menghidupkan kembali dan mempertahankan Islam yang murni. Para penganut sufi sering membentuk kelompok-kelompok sosial yang kuat dan mempunyai banyak pengikut di berbagai belahan dunia. Yang menjadi sebab kenapa hubungan tetap kuat antara mereka adalah karena realitas bahwa selama abad ke-19 rakyat tidak aktif dan kendali atas kepemilikan tanah bersama dengan pengaruh tradisi kultural yang telah lama mapan dapat memainkan peran yang penting dalam menjaga stabilitas masyarakat. Namun pada abad ke-20 kondisi ini semakin berubah dengan cepat dan radikal dengan kesadaran yang mulai pudar dan kekuatan masyarakat semakin renggang.

Ancaman yang keras dari para sekutu untuk menjajah yang dilakukan oleh Barat menjadi sempurna menjelang akhir perang dunia pertama. Kehadiran para penguasa sekuler yang ditunjuk Barat menentukan arah suasana yang memilukan. 
Pengaruh agama pada segala bidang yang semula berjalan secara kuat menjadi rapuh dijadikan nomor dua karena terjadinya erosi yang sangat cepat dalam nilai-nilai dan gaya hidup masa lalu serta tradisional ditambah kenyataan bahwa mengikuti jalan Islam dianggap berbahaya, hal inilah yang menjadikan masyarakat memutar haluan demi untuk mendapatkan jaminan keamanan pada masa itu. Berbeda dengan yang terjadi di negara-negara Barat yang lebih aman karena menjadi negara penjajah yang penduduknya berjalan tertib sehingga perjalanan spiritualnya mulai tumbuh dan berorientasi mencari pengetahuan yang diperoleh dari negara jajahan.

Fenomena menunjukkan bahwa dunia Barat berusaha terlibat dalam gerakangerakan agama adalah benar adanya, sebagaimana yang dilakukan melalui gerakan Bahai dan Subud maupun cabang Budhisme, Hinduisme dan agama-agama baru atau kegiatan yang menghidupkan kembali ajaran-ajaran yang telah lalu sehingga menunjukkan kehausan dan berminat akan penguasaan spiritual.

Konsep yang ditawarkan oleh struktur agama-agama timur menjadi magnet untuk terus digali para orientalis dalam menggali dimensi yang termaktub sebagai lengkah memperbesar minat spiritual dan pencarian pengalaman mistik di Barat, melalui tulisan dan terjemahan atas karya asli tentang tradisi, kesenian, kultur dan falsafah. Gerakan spiritual yang sempat dikaji dan menjadi perhatian adalah dunia tasawuf dan kekuatan yang muncul di dalamnya.

Munculnya perhatian terhadap tasawuf bersamaan dengan datangnya banyak guru India dan ahli kebatinan Budha. Di Eropa dan Amerika Utara mulai bermunculan sekumpulan masyarakat dan gerakan sufi pada pertengahan abad ke-20, sebagian diantara mereka adalah para pengembara sufi yang sebenarnya. Dari waktu ke waktu informasi tentang tasawuf dan Islam semakin komplit di Barat. Terjadinya krisis minyak di sejumlah negara Timur Tengah juga turut membantu dalam meningkatkan hubungan dengan negara tersebut dan bahasa Arab sebagai perantara membawa informasi tentang Islam.

Pada tahun 1979 pecahlah Revolusi Islam Iran yang mengakibatkan bangkitnya perhatian dunia kepada tradisi Islam. Tidak bisa dipungkiri bahwa tempat tinggal Imam Khomeini dan tempat yang biasa dipakai menyambut para tamu di utara Teheran adalah masjid dan tempat suci sufi. Pada dasarnya Imam Khomeini berorientasi pada ilmu tasawuf dan gnosil, pada beberapa tahun permulaan di sekolah 
di Qum beserta tulisannya terutama makna batin dari bangun malam, shalat malam dan kebangunan diri dari tidur lelap dengan dorongan batin yang kuat.

Sejak zaman dahulu tidak dapat diklaim bahwa kualitas spiritual dapat dilihat dari kondisi lahiriah individu seseorang. Imam Ali hanya melibatkan dirinya pada peperangan selama bertahun-tahun sebagai pemimpin umat Islam. Kesederhanaan lahiriah kadang menipu masyarakat dari anggapan sebagai insan yang memiliki spiritual yang kuat.

Ajaran spiritual yang diamalkan kerap merujuk pada Rasulullah Saw, sehingga para syaikh berusaha mendapatkan amalan yang murni melalui silsilah yang datangnya dari Nabi. Menurut (Trimingham 1973:186), silsilah adalah mata rantai spiritual dalam tariqat yang bersambung kepada Nabi Muhammad Saw hingga syaikh yang sekarang.

Jika merujuk pada masa lalu tentang kondisi tasawuf di Barat, dapat diamati dan disimpulkan bahwa banyak kalangan menerima tasawuf karena dapat mengambil manfaat dari beberapa disiplin, doktrin, praktik atau pengalaman. Fraksi-fraksi gerakan yang mengikuti sekian banyak gagasan yang diambil dari tasawuf terpecahpecah karena jalan hidup mereka tidak sejalan dengan garis syariat, sehingga tidak mendapatkan perlindungan dan jaminan keselamatan batin. Pada beberapa abad lalu tampaknya kebanyakan gerakan sufi di Barat semakin menguat karena berpegang pada amal-amal lahiriah atau sebaliknya merosot karena tidak menjalankannya secara kontinyu dan stabil.

Merujuk berkembangnya aliran tasawuf di Indonesia, maka tidak bisa dilepaskan dengan peran serta para penuntut ilmu atau pelajar yang belajar di negara Timur Tengah. Khususnya negara Arab Saudi yang ikut mengantarkan kemurnian Islam dari gerakan tajdid (pembaruan) yang dipelopori oleh Syaikh Muhammad bin Abdul Wahab. Sebagaimana yang disebutkan dalam banyak literatur bahwa pelopor berkembangnya aliran tasawuf di Indonesia diantaranya: Nuruddin ar Raniri, Abdur Rouf as Sinkili, Muhammad Yusuf al Makassari dan sebagainya.

Situasi belajar di kota Makkah inilah sehingga mereka melakukan interaksi keilmuan dengan para syuyukh dari berbagai negara yang tinggal disana. Diantara para syuyukh tersebut yaitu: Ahmad al Quraisy, Ibrohim al Kuroni dan Muhammad al Barzanji. 
Setelah belajar sekian lama, maka Abdur Rouf as Sinkili diangkat menjadi Khalifah Tarekat Syatariyah oleh Muhammad al Quraisy. Dia kembali ke Aceh setelah gurunya meninggal. Di tanah Aceh, as Sinkili cukup terpandang oleh penduduk bahkan menjadi uswah bagi masyarakat, dengan berlandaskan keyakinan yang telah diberikan kepadanya serta kegigihan murid-muridnya, maka dengan mudah mengembangkan ajaran Tarekat sufiyahnya sehingga tersebar ke tanah Minangkabau. Salah satu muridnya yang telah berhasil menyebarkan ajarannya adalah Burhanuddin.

Kuburan Burhanuddin dijadikan pusat ziarah setelah meninggalnya, namun para peziarah banyak melakukan praktek-praktek dan ritual peribadatan yang aneh. Munculnya aliran yang aneh ini mengakibatkan pertentangan yang tajam terutama ketika datangnya orang Arab Saudi yang sudah terindikasi aliran pembaharuan yang dibawa Syaikh Muhammad bin Abdul Wahab. Konflik ini terus berlanjut sehingga terjadinya perang Padri. Inilah faham yang dibawa oleh as Sinkili yang berkembang di Minangkabau dengan ciri khas religiusnya. Demikian juga makam as Sinkili menjadi tempat ziarah dan banyak yang mengunjunginya.

Adapun Muhammad Yusuf al Makassari bertemu dengan gurunya yaitu: Syeikh Abu Barakat Ayyub bin Ahmad bin Ayyub al Kholwati al Khurosy as Syami ad-Dimasqi, kemudian diberi amanah untuk menjadi khalifah aliran Tarekat Khalwatiyah dan diberi gelar Taj al Kholwati. Setelah kembali ke Aceh ia mengembangkan faham Khalwatiyah di sana.

Sementara Nuruddin Muhammad bin Ali bin Muhammad ar Raniri beranjak ke daerah Aceh pada masa kekuasaan Sultan Iskandar Muda. Syamsudin as Sumatrani adalah seorang mufti kerajaan yang ditunjuk pada masa itu, ia termasuk putra kelahiran Aceh yang diberi gelar Ulama dan menganut faham Sufi Wujudiyah. Kedudukan yang strategis itulah yang kemudian dimanfaatkannya untuk mengembangkan fahamnya. Syamsuddin bekerjasama dengan Hamzah Fansuri seorang ulama yang banyak mengungkapkan pemahamannya dengan melalui prosa.

Di samping tokoh-tokoh di atas, masih ada lagi tokoh yang sebelumnya melakukan studi di Timur Tengah serta pulang ke tanah air dan menyebarkan ajaran tasawuf diantaranya: Abdus Shomad al Palimbani dan Muhammad Arsyad al Banjari (mampu merombak wajah kerajaan Banjar di Kalimantan Selatan, bahkan beberapa 
karyanya banyak dikaji di berbagai wilayah Indonesia dan Asia Tenggara diantaranya Sabil al Muhtadin yang diabadikan sebagai nama masjid besar di kota Banjarmasin).

Dua tokoh di atas beserta sahabatnya (Abdul Wahab dan Abdurrahman) merupakan penganut tarekat yang berguru kepada Syaikh Muhammad as Saman. Disamping nama-nama di atas, juga ada yang lainnya seperti: Nawawi al Bantani, Ahmad Khotib as Sambasi, Abdul Karim al Bantani, Ahmad Rifa'i Kalisasak, Junaid al Batawi, Ahmad Nahrowi al Banyumasi, Muhammad Mahfudz at Termasi, Hasan Mustofa al Garuti dan lain sebagainya.

Namun tidak semua orang yang pulang dari studi di Timur Tengah membawa ajaran baru dan masuk dalam faham tasawuf, salah satu yang tidak masuk ke dalamnya yaitu Ahmad bin Khotib bin Abdul Latif al Minangkabawi. Ia merupakan tokoh yang tidak terpengaruh dengan dunia tarekat manapun dan memfatwakan kepada umat untuk kembali pada ajaran Islam yang benar berdasarkan al Quran dan al Hadits dan menghindarkan diri dari perbuatan syirik serta mengharamkan penghadiran guru ketika beribadah sebagaimana yang banyak dilakukan oleh penganut tarekat Naqsabandiyah.

Di negara Indonesia dewasa ini dikenal dua macam kelompok tarekat yang berkembang, yaitu tarekat Mu'tabarah dan tarekat Ghairu Mu'tabarah. Adapun tarekat yang diklaim sebagai tarekat Mu'tabarah diantara: Qodiriyah, Naqsabandiyah, Tijaniyah, Syathariyah, Syadziliyah, Khalidiyah, Samaniyah, Alawiyah dan lain-lain seperti yang saat ini digagas oleh kalangan NU yaitu tarekat Nahdhiyah. Adapun yang paling banyak pengikutnya adalah tarekat QodiriyahNaqsabandiyah.

Perkembangan tarekat Qodiriyah-Naqsabandiyah cukup meluas terutama di daerah Jawa Barat yang tepatnya di pesantren Suryalaya Tasikmalaya. Berdasar silsilah yang beredar bahwa keberadaan tarekat Qodiriyah-Naqsabandiyah di pesantren ini berasal dari Mursyid Ahmad Khatib as Sambas. Ia memiliki tiga orang murid yang bernama Syaikh Abdul Karim al Bantani, Syeikh Khalil Bangkalan dan Syeikh Thalhah dari Cirebon. Dari Syeikh Thalhah inilah Abah Sepuh (ayah dari pengasuh pesantren Suryalaya Abah Anom atau kyai Shahibul Wafa' Tajul Arifin) 
menerima estafet Tarekat Qodiriyah-Naqsabandiyah dan diturunkan kepada putranya.

Adakalanya untuk masuk pada suatu tariqat, diharuskan melalui bagian dari upacara yang mana sang murid menyatakan sumpah setia kepada syaikhnya, setelah itu murid diperbolehkan turut serta dalam ritual-ritual bersama dalam tariqat itu (Bruinesen, 1998). Bahkan sudah lazim bahwa, seorang murid ikut serta menyebut syaikhnya dalam rangka merealisasikan kesetiaan kepadanya.

Hal ini kerap dilakukan karena didasarkan asumsi bahwa hati sang guru itu ibarat sebuah pancuran yang melimpah dari lautan yang luas ke dalam hati murid yang murabit. Untuk menyauk berkah darinya, karena sang guru adalah mediator untuk sampai kepada Tuhan (Kurdi, 1994: 444).

Tuntunan al Ghazali dalam Ihya' Ulum al Din dan Bidayah al Hidayah diterjemahkan oleh para pengikut di sekitarnya dengan kelahiran amaliah-amaliah yang memerlukan panduan guru (syaikh). Jalan tasawuf biasanya diikuti dalam konteks kelompok. Kelompok para salikin (pencari Tuhan) yang mengitari Syaikhnya, hal ini biasa disebut sebagai halaqah (lingkaran). Para anggota halaqah berhubungan erat sebagai sesama musafir di jalan menuju Tuhan. Pada akhirnya lingkaran-lingkaran awal ini bergabung membentuk tarekat (Sviri, 2002: 207)

Masih banyak lagi ragam tarekat selain disebutkan di atas yang berkembang di Indonesia dan pada hakekatnya penganut tarekat juga memiliki gairah yang kuat untuk menjaga kemerdekaan bangsa ini. Di Jawa Barat berkembang tarekat Idrisiyah, Qodiriyah-Idrisiyah, Syathariyah, Syathariyah-Muhammadiyah, tarekat Lahir Bathin dan tarekat Tijaniyah (pusat penyebarannya di Cirebon, sementara di Sumatera Selatan berkembang menjadi Tarekat Shalawat).

\section{Mengamati Dunia Tasawuf di Era Modern}

Dunia tasawuf semakin merambah ke berbagai bidang baik di pedesaan sampai di perkotaan, banyak kalangan ikut berkecimpung sekalipun dari kalangan menengah ke atas. Mereka masuk ke dunia tersebut karena demi mendapatkan ketenangan batin dan menyelaraskan kehidupan yang penuh dengan dekadensi moral yang tiada batasnya. 
Kecenderungan terhadap spiritualitas Islam, baik yang terikat secara formal dalam konteks tarekat misalnya, maupun yang non formal, masih akan terus berlangsung, baik di daerah pedesaan maupun perkotaan, baik oleh rakyat biasa ataupun oleh pejabat dan petinggi negara. Apalagi ketika masyarakat sudah mulai merasa jenuh dengan kehidupan hedonistis di satu sisi, ataupun kehampaan dan kegersangan hati dari ketergantungan kepada yang transenden menjadikan keperluan terhadap dunia spiritual menjadi semakin kuat (Mulyati, 2007).

Krisis moral yang dialami oleh masyarakat kota terjadi karena tuntutan modernisasi yang mengharuskan setiap pribadi lebih mementingkan individu ketimbang orang lain sekalipun harus memakan sendiri kawannya, sehingga kondisi ini akan mengakibatkan perilaku yang kelewat batas serta jauh dari nilai-nilai persaudaraan dan kekeluargaan yang seharusnya dimiliki oleh setiap manusia sebagai makhluk sosial.

Ciri khas modernisasi dan manusia modern adalah tingkat berfikir, iptek dan sikapnya terhadap penggunaan waktu dan penghargaan terhadap karya manusia (Jumantoro 2005: xii)

Atho' Muzhar mengemukakan bahwa masyarakat modern ditandai oleh 5 hal (Jumantoro: 2005)

1. Berkembangnya mass culture.

2. Tumbuhnya sikap menghargai kebebasan.

3. Tumbuhnya berpikir rasional.

4. Tumbuhnya sikap materialistis.

5. Meningkatnya laju Urbanisasi seperti yang dikemukakan juga oleh Amin Syukur (2000:177)

Ada beberapa efek negatif yang ditimbulkan oleh transformasi nilai budaya modern, yaitu:

1. Tiada lagi perasaan malu untuk berbuat maksiat.

2. Kontrol masyarakat yang lemah.

3. Arus budaya barat yang kian kencang.

4. Media informasi yang tidak lagi mendidik.

Pada saat dunia tasawuf dihadapkan pada era modernitas, maka benang merah yang paling nyata adalah anggapan bahwa tasawuf dan masyarakat modern 
merupakan dua aspek yang berbeda bahkan salah berlawanan antara satu dengan yang lain. Nilai-nilai tasawuf kadang kala dianggap bagai mata pisau yang tidak akan pernah bertemu dengan nilai-nilai hidup masyarakat modern. Ajaran yang berbentuk konsep maqamat dan ahwal diklaim sebagai aspek doktrin yang merepresentasikan kehidupan yang tradisional dan sederhana, antipati pada dunia, pasrah dan rendah hati yang hanya cocok diaplikasikan pada kehidupan tradisional.

Melalui pemaparan di atas, maka memang tasawuf tidak dapat diterapkan pada dunia modern, sebab modern lebih banyak diselingi dunia kemewahan, pemujaan materi, persaingan individu beserta intrik dan tipu daya, keserakahan, cinta dunia, keangkuhan, kekerasan dan sebagainya.

Yang lebih memprihatinkan adalah adanya anggapan seperti ini bukan hanya datang dari kalangan modernis, tapi juga banyak kalangan tradisional mengatakan demikian. Pandangan seperti ini harus dikaji ulang untuk mendapatkan pengetahuan tentang tasawuf dan sufisme yang sebenarnya sehingga tidak ada kesan bahwa tasawuf hanyalah diperuntukkan bagi orang yang kuno dan anti peradaban mutakhir.

Pada dasarnya tudingan mengenai sufisme mengabaikan kehidupan duniawi tidak dapat dibenarkan karena sebenarnya sufisme adalah mementingkan keseimbangan antara jasmani dan rohani, spiritual dan materiil sehingga terjadi hubungan yang positif antara vertikal (habl min Allah) dan horizontal (habl min al nas).

Secara umum memang tidak bisa dipungkiri bahwa kecintaan manusia pada dunia, mengejar serta larut dalam kenikmatan dan kesenangannya, biasanya dipengaruhi beragam faktor. Faktor terpenting adalah raibnya keimanan pada kehidupan akhirat.

Agama Islam tidak menyeru untuk menghindar dari kehidupan dunia, bahkan mengajak untuk mencari anugerah hidup di dunia dan menjadikannya sebagai sarana merengkuh akhirat. Pengembangan spiritual hanya bisa dipenuhi melalui hidup yang shaleh di tengah-tengah gemerlapnya dunia tanpa harus menghindar. Bahkan Allah di dalam al Quran menyuruh manusia mencari kebaikan di dunia juga di akhirat, ini tidak bisa dicapai tanpa ikut terlibat di dunia dan keterlibatan tersebut dijadikan sarana menuju akhirat. Namun ajaran Islam mengarahkan untuk makan dan minum tetapi tidak boleh berlebihan melebihi yang seharusnya. 
Arahan di atas menjadi landasan untuk hidup sederhana dan tidak saling menjegal kawan serta berupaya menumpuk harta untuk kelanggengan hidup di dunia. Dari sini dapat ditunjukkan bahwa para sufi tidak boleh menjauhi kehidupan dunia bahkan mereka harus memberikan sumbangan yang besar bagi kehidupan sosial masyarakat. Dalam bidang pendidikan zaman Khawajah Nizam al Mulk Dinasti Saljuk berpartisipasi langsung membangun universitas-universitas atau madrasah dimana mereka adalah para pengembara atau sufi.

Di bidang politik dan militer juga tidak kalah penting, tarekat-tarekat sufi berperan menjadi kekuatan politik, di berbagai Negara Islam, karena dalam Hadits Nabi Saw diwajibkan untuk cinta tanah air dan mempertahankannya. Tarekat Safawi misalnya berubah dari gerakan spirituil semata menjadi gerakan politik dan militer yang akhirnya berhasil mendirikan kerajaan Safawi di Persia. Hal yang sama misalnya peran para sufi dalam menumpas penjajah kolonial di Indonesia, sehingga semangat sufisme mempunyai sumbangan besar bagi pencapaian kemerdekaan negara Indonesia ini.

Konsep di atas tentunya menepis anggapan bahwa tasawuf anti dunia dan untuk mengamalkan ajaran tasawuf harus ikut andil dalam kehidupan masyarakat yang mendambakan kedamaian hidup, sehingga bisa dibayangkan jika setiap manusia mau untuk mengamalkan nilai tasawuf tentunya dunia akan aman dan bebas dari keserakahan dan kejahatan.

Mengikuti ajaran tasawuf memang beralasan untuk merespon kemiskinan spiritual masyarakat modern di tengah gemerlapnya dunia terutama di Barat. Hal tersebut cukup beralasan, karena tasawuf mengajarkan hal-hal yang rasional dan sekaligus supra rasional yang tidak bisa dijangkau dengan rasio biasa. Pemahaman terhadap ajaran agama secara rasional disertai aplikasi secara formal tidak cukup menjamin kesetiaan kepada agama, karena ketika orang tersebut mengalami gangguan dalam hidupnya maka dia akan mempertanyakan ibadah yang telah dilaksanakan dengan tekun. Dengan demikian pemahaman tentang tasawuf akan mengantarkan pada kenikmatan batin dan sekaligus membuat penganutnya lebih setia terhadap agama serta mengangkat motivasi yang tak terhingga.

Nilai tasawuf zaman sekarang telah dikemas sedemikian rupa dengan mengintegrasikan filsafat, pemikiran, ilmu pengetahuan dan disiplin kerohanian 
tertentu berdasarkan ajaran Islam. Kandungan yang digali dari al Quran dan al Hadist serta dari pengalaman keagamaan telah dikembangkan oleh para sufi.

Pelaksanaan nilai tasawuf di zaman modern hendaknya diposisikan secara porposional, dalam arti tidak menutup kemungkinan adanya salik atau pengembara sufi yang mengaplikasikan sufistik melalui maqam-maqam mulai dari awal sampai puncaknya sehingga ia akan menjauhi hidup yang dipenuhi materi keduniaan, akan tetapi orientasi kesufian hendaknya diarahkan dapat berkembang seiring dengan lajunya arus modernisasi.

Yang perlu mendapat perhatian adalah bagaimana mengamalkan nilai spiritual maqamat dan ahwal di tengah arus modernitas. Pengertian zuhud tidak selalu diartikan menyendiri dari perkumpulan masyarakat untuk menyatu dengan Tuhannya, tetapi penyucian dimaksud tetap ikut terlibat dalam dinamika dunia modern.

Ajaran tasawuf di zaman modern menjadikan orang yang mampu menghadirkan ke dalam dirinya nilai-nilai Ilahiyah yang memancar dalam perilaku sehari-hari yang baik dan menyinari kehidupan sesama manusia dengan amal shaleh. Hal ini tentunya berdasarkan hadits Rasulullah SAW, yang mengarahkan manusia menjadi orang yang bermanfaat bagi sesama manusia.

Kesan bahwa sufi harus menjauhkan diri dari masyarakat (uzlah) dan sibuk dengan ibadahnya sendiri, seperti yang digambarkan oleh para pihak, bahwa untuk mengamalkan praktik kesufian hanyalah dengan penyendirian dengan tujuan menyatu dengan Tuhan, tampaknya merupakan hal yang kurang relevan dengan modernitas yang mengharuskan adanya hubungan antar pribadi dan kelompok manusia dalam membangun peradaban modern yang cirinya adalah pemanfaatan iptek dan pendayagunaan sumberdaya secara maksimal serta kemakmuran kehidupan. Untuk itu, diperlukan orientasi baru berupa penghadiran nilai-nilai Ilahi dalam perilaku keseharian manusia modern, sehingga peran agama yang menghendaki kesucian moral tetap terasa sangat perlu. Hal ini berarti, pengamalan ajaran agama tidak cukup jika hanya bersifat rasional dan formal tanpa kesadaran batiniyah yang mendalam, sehingga setiap muslim dapat merasakan nikmatnya beragama, yang di dalamnya terkandung kecintaan kepada Tuhan sekaligus kecintaan kepada sesama manusia dan sesama makhluk. 
Untuk itu, tasawuf di abad modern tidak lagi berorientasi murni kefanaan untuk menyatu dengan Tuhan, tetapi juga pemenuhan tanggung jawab manusia sebagai khalifah Tuhan yang harus memperbaiki dirinya dan sesama makhluk. Dengan kata lain, tasawuf tidak hanya memuat dimensi kefanaan yang bersifat teofani, tetapi juga berdimensi profan yang di dalamnya terdapat kepentingan sesama manusia yang mendunia.

Dalam masyarakat Indonesia selama dua puluh tahun ini mengalami perubahan drastis yaitu, sufisme yang selama ini hanya dikenal oleh masyarakat pedesaan sekarang merambah dunia perkotaan sebagai aktifitas rutin mereka. Hal ini terjadi karena dua hal diantaranya; perpindahan penduduk desa yang mengamalkan tasawuf ke kota dan usaha penduduk kota yang bermasalah dengan motif mencari ketenangan ke desa. Menurut Jalaluddin Rahmat bahwa sufisme banyak diminati masyarakat kota karena bisa menjadi alternatif terhadap bentuk-bentuk keagamaan yang kaku.

Sufisme masyarakat kota dipetakan menjadi dua model utama; sufisme kontemporer yang menekankan pada aktifitas sufi yang memudahkan siapapun masuk dan berkecimpung secara langsung dalam ritualnya, seperti yang sering dilakukan dalam pengajian eksekutif Paramadina, Tazkia Sejati, Pengajian Pesantren al Rifa'ie Gondanglegi Malang dan di berbagai kelompok lainnya. Dan yang kedua; sufisme konvensional yang berbentuk tarekat seperti yang disebutkan di atas dan beberapa diantaranya mengharuskan dibaiat terlebih dahulu untuk diregister menjadi salah satu murid atau anggota, serta ada juga yang non tarekat seperti banyak dianut kalangan Muhammadiyah yang merujuk pada Buya Hamka dan Syaikh Khatib al Minangkabawi sebagai guru spiritual mereka.

Tempat-tempat yang kerap dijadikan sebagai wahana melakukan tindak tarekat dinamakan Khanaqah yang dijadikan sarana rutinisasi amaliyah sufisme. Term yang sama digunakan di Mesir Tengah. Khanaqah dibentuk sebagai pusat budaya dan teologi dari para sufi (Lapidus, 1999: 258)

Namun dalam kenyataannya, model tarekat lebih bisa diterima masyarakat menengah ke bawah ketimbang model non tarekat yang lebih banyak dipilih oleh kalangan masyarakat menengah ke atas karena tidak perlu harus diadakan berbagai riyadhoh sebagai sarana pembinaan mental. 
Disamping alasan diatas, juga karena ritualnya yang singkat dan instan. Pengembaraan tasawuf bagi masyarakat perkotaan diibaratkan orang yang mengalami sakit kemudian gundah dan berharap masalahnya segera berakhir. Ada beberapa komponen yang dirasa berat bagi mereka jika masuk dalam tarekat, diantaranya; adanya mursyid, murid, wirid, tata aturan dan tempat tertentu, sehingga berat bagi mereka untuk dipenuhi terutama aturan yang mengharuskan baiat setia kepada guru. Ritualnya juga tidak dimungkinkan pada wirid yang terlalu lama dan panjang serta mengharuskan berpuasa sekian lama.

Demikianlah sisi-sisi lain dari tasawuf yang memberikan gambaran tentang eksistensinya di masyarakat dengan berbagai amal yang dilakukan dan bahkan menjadikan calon pengikutnya merasa berpikir ulang untuk mengikuti amalan yang mengharuskan masuk dalam tarekat yang sebagian mengharuskan baiat terlebih dahulu.

\section{Simpulan}

Dari pemaparan di atas, tampak jelas bahwa sebenarnya ajaran tasawuf tidak memberikan justifikasi tentang konsep zuhud untuk menjauhkan diri dari dunia dengan berbagai gemerlapnya, melainkan zuhud bermaksud merangkul dan menjadikan dunia sebagai sarana untuk menuju akhirat serta tetap hidup bermasyarakat sebagaimana mestinya. Ajaran tasawuf juga mengajarkan bahwa kita hidup di dunia memerlukan sarana dan sarana itu ada dalam kehidupan dunia yang tidak bisa ditinggalkan tetapi perilaku kita mencerminkan cahaya Ilahiyah.

\section{Daftar Pustaka}

Jumantoro, Totok, dan Samsul Munir Amin, 2005. Kamus Ilmu Tasawuf. Wonosobo: Amzah.

Kurdi, Muhammad Amin, 1994. Tanwir al-Qulub fi Mu'amalat 'Allam al-Ghuyub. Tt: Dar al-Fikr.

Lapidus, Ira M, 1999. Sejarah Sosial Umat Islam. Jakarta: Raja Grafindo Persada.

Mulyati, Sri, 2007. Dakwah Tasawuf di Dunia Modern. Makalah disampaikan pada Pelatihan Muballigh Tasawuf V di Jakarta 17 - 19 Agustus 2007. 
Siregar, Rivay, 2000. Tasawuf dari Sufisme Klasik ke Neo Klasik. Jakarta: Raja Grafindo Persada.

Sviri, Sara, 2002. Demikianlah Kaum Sufi Berbicara. Bandung: Pustaka Hidayah.

Syadzili, Ahmad Fawaid. Ensiklopedi al Quran. Jakarta: PT. Kharisma Ilmu, Jilid 4 Syukur, Amin, 2000. Zuhud di Abad Modern. Yogyakarta: Pustaka Pelajar.

Trimingham, J Spencer, 1973. The Sufi Orders In Islam. London: Oxford University Press.

Van Bruinesen, Martin, 1998. Tarekat Naqsyabandiyah di Indonesia. Bandung: Mizan. 